\title{
Iron Asseveration in Soil, Forage and Animals Blood and Feces Samples Collected from Different Districts of Punjab, Pakistan
}

\author{
Ijaz Rasool Noorka ${ }^{1,2 *}$, Bilal Ahmad Khan ${ }^{3 *}$, Kafeel Ahmad ${ }^{4}$, Zafar Iqbal Khan ${ }^{4}$, Muhammad Ather \\ Nadeem $^{3}$, Amer Nawaz ${ }^{2}$, Tasneem Ahmad ${ }^{5}$ and Humayun Bashir ${ }^{4}$
}

${ }^{1}$ Department of Plant Breeding and Genetics, College of Agriculture, University of Sargodha, Sargodha, Pakistan; ${ }^{2}$ Department of Plant Breeding and Genetics, Ghazi University, Dera Ghazi Khan, Pakistan; ${ }^{3}$ Department of Agronomy, College of Agriculture, University of Sargodha, Pakistan; ${ }^{4}$ Department of Botany, University of Sargodha, Sargodha, Pakistan; ${ }^{5}$ Pakki Thatti $R$ and D Farm, Toba Tek Singh, Pakistan.

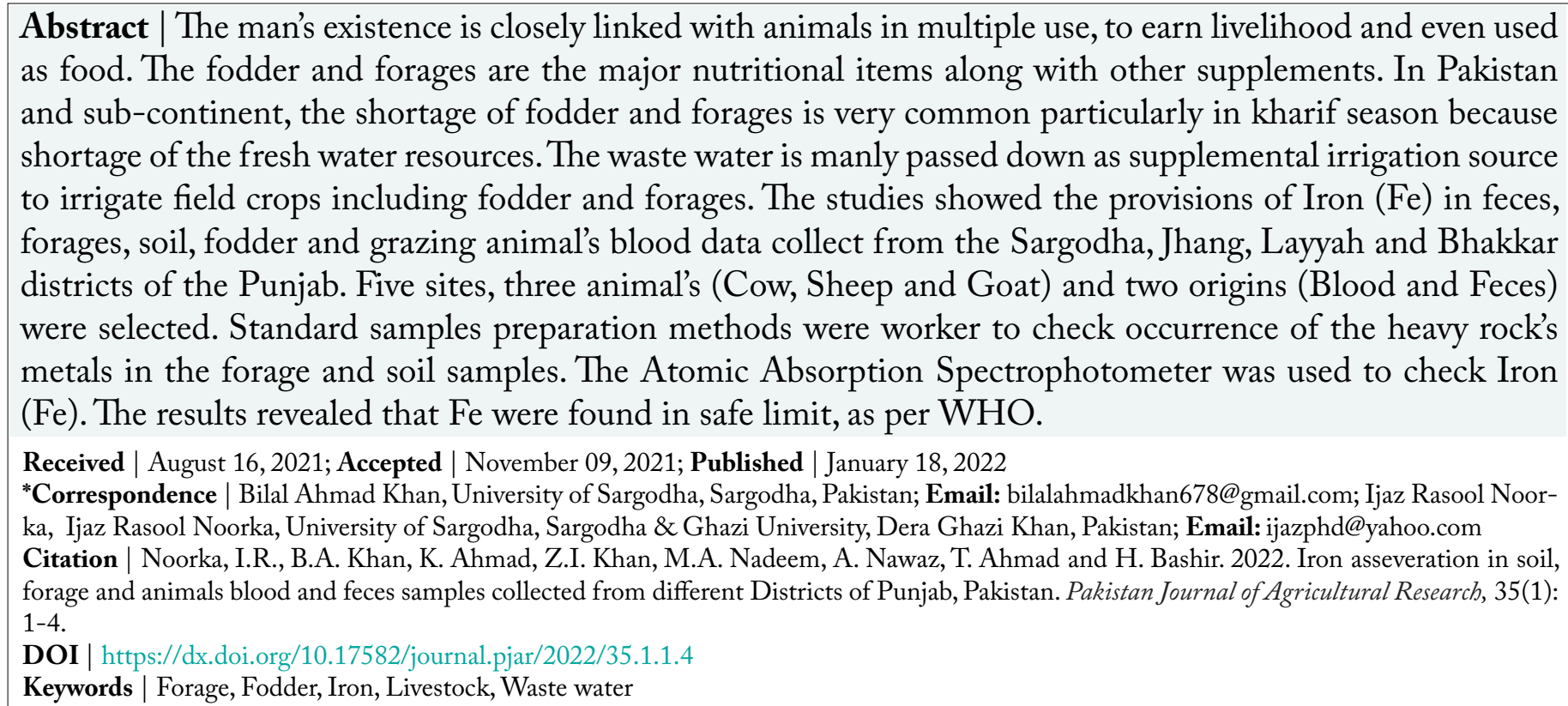

\section{Introduction}

A griculture and livestock are intimately connected to man's life, especially in rural regions. It is the world's largest livestock business, which endures hot and humid weather around the clock (Noorka et al., 2020). The survival of livestock is an important element of our civilization in the face of changing environmental circumstances. It isn't only the desire to raise animals that motivates people to do so (Noorka and Heslop-Harrison, 2019; Noorka, 2020). For the animal's own survival, a survival ship is a key priority. Indeed, numerous environmental elements such as temperature, geography, and genetic differences all have a role in improving the nutritional values of fodder and forages for cattle (Noorka, 2020; Noorka et al., 2017; Noorka et al., 2020). Animal feed quality differ from location to location (Habib and Siddique, 1994).

In the current world, countries that utilize grain as ruminant feed get 75 percent of their nutrition from forages for ruminants. Those nations who did not rely on grains as a source of fodder, on the other hand, would get 95 percent of their ruminant nutrition from roughage (Bulla et al., 1977). The main winter fodder is berseem (Ali et al., 2020). 
"Sarson" is the most prevalent fodder, mustard or "rai" are also utilized as fodder. As a minor winter crop, barley (Hordeum sativum) and Hordeum vulgare are cultivated. Vetches (Vicia spp.) have a good track record in trials but aren't widely used as a staple. The animal is also fed dry foods (Al-Saleem et al., 1996). Pesticides, fertilizers, and soil crops all contribute to the accrertion of heavy rocks metals (Onianwa, 2001).

Agricultural supplemental irrigation is one of the primary applications of wastewater (Noorka, 2020). The number of heavy metals that accumulate in waste-water irrigated soils is determined by the length of time that it is applied (Noorka and Heslop-Harrison, 2019). Despite having the worldwide biggest canals irrigation system, Pakistan's decreasing freshwater supplies have forced farmers to use wastewater as a supplemental or even exclusive source of water. In urban regions of poor nations, the waste water is utilized on agricultural lands to satisfy water shortages. Keeping in mind the goals of determining Fe levels in fodders and forages under the control and wastewater conditions.

\section{Materials and Methods}

Samples of soil, fodder, forage and animals (urine, blood, feces and hairs) were collected form all sits. Fresh fodder and forage samples were collected from different sites of Bhakkar, Layyah, Jhang and Sargodha districts (Figure 1). Most of the fodder and forage consumption during both summer and winter seasons were managed from these sites. Three Blood samples (Sheep, Goat and Cow) were taken from Bhakkar, Layyah, Jhang and Sargodha districts. Sites and treatments of the experiment are of following.

$\begin{array}{llll}\text { S1: Control } & \text { D1: Sargodha } & \text { A1: Goat } & \text { S1: Blood } \\ \text { S2: Waste water } & \text { D2: Jhang } & \text { A2: Sheep } & \text { S2: Feces } \\ \text { S3: Waste water } & \text { D3: Layyah } & \text { A3: Cow } & \\ \text { S4: Waste water } & \text { D4: Bhakkar } & & \\ \text { S5: Waste water } & & & \end{array}$

Samples digestion, heavy metal determination and sample preparation by wet digestion method were done by revealed by [10]. Dried samples were digested with concentrated $\mathrm{H}_{2} \mathrm{O}_{2}$ and $\mathrm{HNO}_{3}$ (2:1) on hot plate. This process continued until the appearance of colorless solution.
Metals concentration

For the determination of heavy metals, processed samples ware passed through the Atomic Absorption Spectrophotometer.

\section{Statistical analysis}

Recorded data was analyzed by using SAS software 9.2. Date was analyzed by using Comparison of results done with international results given by USPEA (US Environmental Protection Agency).

\section{Results and Discussion}

\section{$\mathrm{Fe}$ in Soil}

Table 1 depicted that the $\mathrm{Fe}$ values were significantly affected by sites, districts and site $\times$ districts. $\mathrm{Fe}$ in the soil ranged from $17.75-27.53 \mathrm{mg} / \mathrm{kg}$. Site 1 (Sargodha) showed the lowest value, while, site 2 (Bhakkar) showed the highest value (Figure 1). Fe values were frequently lower than the critical levels (150 mg/kg) declared by (WHO, 1989).

$\begin{array}{lllll}\text { Table 1: Analysis of variance of Fe in soil sample. } \\ \text { Sources } & \text { D } & \text { S.S } & \text { M.S } & \text { F value } \\ \text { Districts } & 3 & 352.187 & 117.396 & 18.321^{*} \\ \text { Sites } & 4 & 35.496 & 8.874 & 1.385^{*} \\ \text { Districts } \times \text { Sites } & 12 & 107.669 & 8.972 & 1.400^{*} \\ \text { Error } & 40 & 256.302 & 6.408 & \\ \text { Total } & 60 & 29882.364 & & \end{array}$

\section{Forage}

Data about the forage shown a significant effect on sites, districts and site $\times$ districts (Table 2). Fe in the forage ranged from $20.72-29.41 \mathrm{mg} / \mathrm{kg}$. Lower values were observed from site 5 of Bhakkar and highest values was examined under site 3 of Jhang (Figure 2). $\mathrm{Fe}$ in the forage was also lower than the critical value $(40 \mathrm{mg} / \mathrm{kg})$ declared by $(\mathrm{WHO}, 1989)$.

Table 2: Analysis of variance of $\mathrm{Fe}$ in forages sample.

$\begin{array}{lllll}\text { Sources } & \text { DF } & \text { S. S } & \text { M.S } & \text { F value } \\ \text { Districts } & 3 & 155.818 & 51.939 & 28.921^{*} \\ \text { Sites } & 4 & 95.095 & 23.774 & 13.238^{*} \\ \text { Districts } \times \text { Sites } & 12 & 94.479 & 7.873 & 4.384^{*} \\ \text { Error } & 40 & 71.837 & 1.796 & \\ \text { Total } & 60 & 38802.898 & & \end{array}$

\section{Animals}

A significantly different effect was observed about 
animals of districts, animals, sources, districts $\mathrm{x}$ animals, districts x sources, animals $\mathrm{x}$ sources and districts $\mathrm{x}$ animals $\mathrm{x}$ sources (Table 3 ). Fe ranged from $2.38-5.39 \mathrm{mg} / \mathrm{kg}$ in animals. Fe concentration in animals blood samples were higher than the critical values determined by the (WHO/FAO, 2007).

Table 3: Analysis of variance of $\mathrm{Fe}$ for animals.

$\begin{array}{lllll}\text { Sources } & \text { DF } & \text { S.S } & \text { M.S } & \text { F value } \\ \text { Districts } & 3 & 15.442 & 5.147 & 4.796^{*} \\ \text { Animals } & 2 & 9.270 & 4.635 & 4.319^{*} \\ \text { Sources } & 3 & 116.778 & 38.926 & 36.268^{*} \\ \text { Districts } \times \text { Animals } & 6 & 10.369 & 1.728 & 1.610^{*} \\ \text { Districts } \times \text { Sources } & 9 & 36.669 & 4.074 & 3.796^{*} \\ \text { Animals } \times \text { Sources } & 6 & 7.693 & 1.282 & 1.195^{*} \\ \text { Districts } \times \text { Animals } \times \text { Sources } & 18 & 29.346 & 1.630 & 1.519^{*} \\ \text { Error } & 432 & 463.658 & 1.073 & \\ \text { Total } & 480 & 6913.480 & & \end{array}$

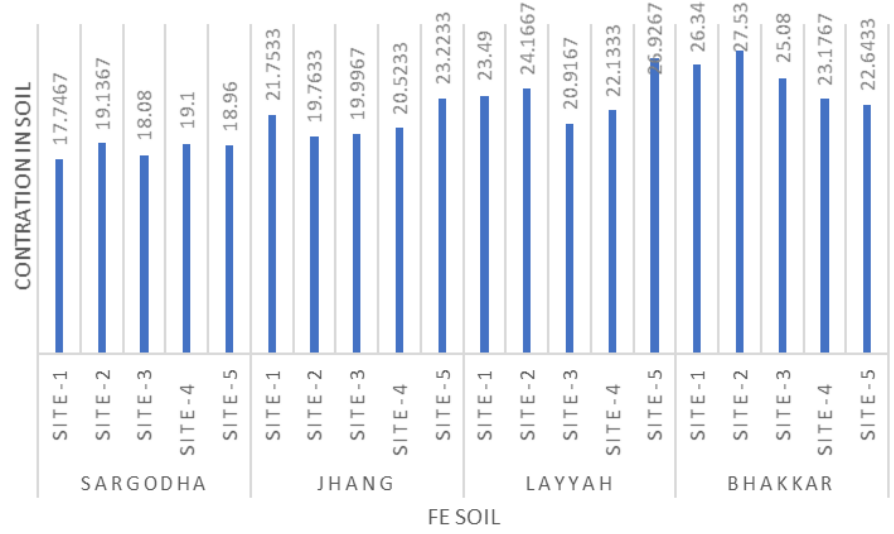

Figure 1: Graph of concentration of $\mathrm{Fe}$ found in soil of districts of Sargodha, Jhang, Layyah and Bhakkar.

The results depicted that the diverse amount of $\mathrm{Fe}$ was found among the samples obtained from districts from the five different sites (Sargodha, Layyah, Jhang and Bhakkar) of Punjab. The graph showed that District Bhakkar site 2 found maximum amount of $\mathrm{Fe}$ in its sample followed by site 5 of district Layyah.

The results showed that the concentration of Fe was found among the samples (Blood and Urine) obtained from animals (Goat, Sheep, Cow) from districts of Sargodha, Jhang, Layyah and Bhakkar. The graphical representation showed that the feces sample obtained from the sample of goat revealed maximum amount of Fe, similarly the feces sample obtained from cow at District Jhang was at number 2, followed by feces of goat at district Bhakkar.

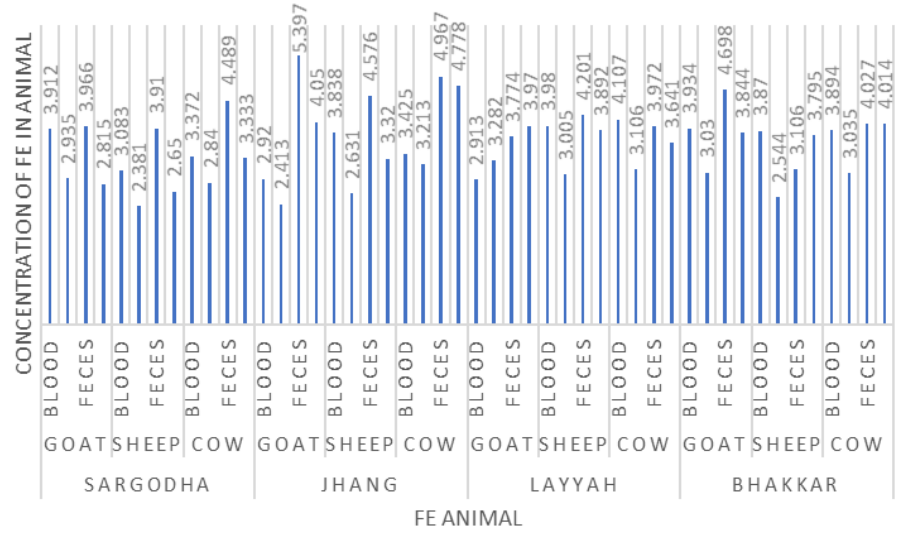

Figure 2: Graph of concentration of $\mathrm{Fe}$ found in animal (Goat, Sheep and Cow) in blood, Urine, hair and feces districts of Sargodha, Jhang, Layyah and Bhakkar.

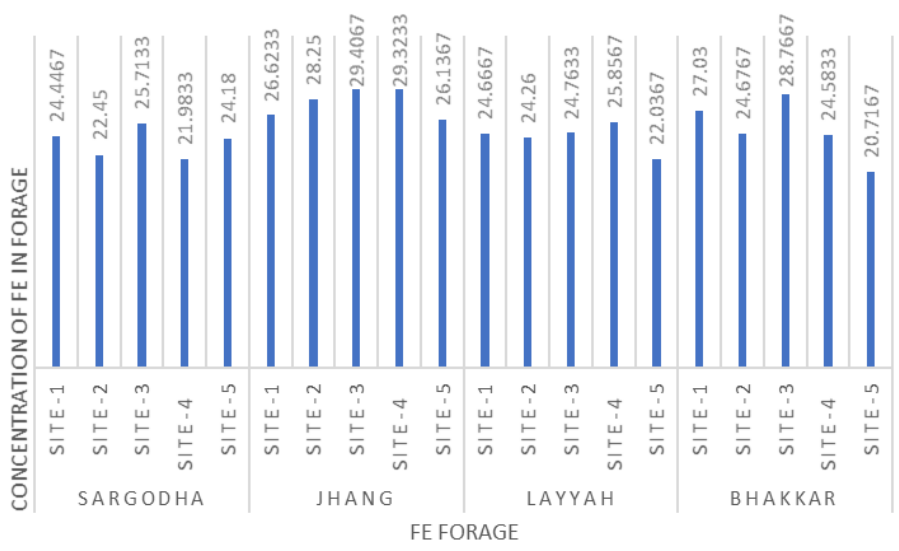

Figure 3: Graph of concentration of Fe found in forage of districts of Sargodha, Jhang, Layyah and Bhakkar.

The graph results showed differential amount of $\mathrm{Fe}$ was found among the samples obtained from five different sites. District Jhang site 3 found maximum amount of $\mathrm{Fe}$ in its sample followed by site 4 of same district.

\section{Conclusions and Recommendations}

World health organization reported that environmental pollution causes many diseases facing the mankind today. Irrigation with normal and polluted water have diverse effects and it contaminated the soil and cultivated land. Farming on the polluted soil may lead to heavy metal accumulation in crops edible parts, which resulting high risk to human as well as animal health. The current study concluded that Fe concentration of blood samples of cow, goat and sheep were found greater than the respective permissible limits. Therefore, this study may also help to found a baseline data to check sewage irrigation in coming time.

There is dire need for an affluent monitoring of the contamination levels of heavy metals at diverse crop 
varieties, their crosses, their mode of tolerance molecular levels since they can accumulate to toxic levels.

\section{Acknowledgement}

The first author is acknowledged for financials support through research projects \# Number: UOS/ ORIC/2016/12.

\section{Novelty Statement}

This study revealed that Fe was found in safe limit, as per WHO in Sargodha, Jhang, Layyah and Bhakkar districts of the Punjab and three animal's (cow, sheep and goat) and two origins (blood and feces).

\section{Author's Contribution}

Ijaz Rasool Noorka and Zafar Iqbal Khan: Conceived the idea.

Bilal Ahmad Khan and Kafeel Ahmad: Wrote abstract and planned methodology.

Muhammad Ather Nadeem: Did SPSS analysis.

Amer Nawaz: Wrote conclusion

Tasneem Ahmad and Humayun Bashir: Provided technical input at every step.

\section{Conflict of interest}

The authors have declared no conflict of interest.

\section{References}

Ali, W., M. Ali, M. Ahmad, S. Dilawar, A. Firdous and A. Afzal. 2020. Application of Modern Techniques in Animal Production Sector for Human and Animal Welfare. Turk. J. Agric. Food Sci. Tech., 8(2): 457-463. https://doi. org/10.24925/turjaf.v8i2.457-463.3159

Al Salem, S.S. 1996. Environmental considerations for wastewater reuse in agriculture. Water Sci. Tech., 33(10-11): 345-353. https://doi. org/10.2166/wst.1996.0692

Bula, R.J., V.L. Lechtenberg, D.A. Holt, L.R. Humphreys, L.V. Crowder and T.W. Box. 1977. Potential of the world's forages for ruminant animal production. Winrock International Research and Training Center, Petit Jean Mountain, Morrilton, Arkansas, USA.

Habib, G and M.M. Siddique. 1994. Feeds and feeding. In: Animal husbandry, Shah, S. I, Bashir, E., and Bantel, R. (Editirs), pp. 177-205, National Book Foundation Islamabad.

Noorka I.R and J.S. Heslop-Harrison. 2019. Cross disciplinary drivers to benefit smallholder farmer communities and to achieve the SDGs by various means. In: Leal Filho W. (eds) Handbook of Climate Change Resilience. Springer. https://doi.org/10.1007/978-3-31993336-8 40

Noorka, I.R. 2020. Climate risks and adaptation to crop yield in Pakistan: toward water stress tolerance for food security. Climate Action, 299-307. https://doi.org/10.1007/978-3-31995885-9 113

Noorka I.R., Taufiqullah, J.S. Heslop-Harrison and T. Schwarzacher. 2017. The agriculturenutrition-health nexus at the cost of water availability in maize diverse genotypes to ensure food security. Int. J. Water Res. Arid Environ., 6: 242-251.

Noorka I.R., K. Ahmad, Z.I. Khan and H. Bashir. 2020. Zinc asseveration in fodder, forages, soil, grazing animals, hairs, blood, urine and feces collected from different districts of Punjab. Pakistan. Int. J. Biosci., 17(6): 400-407.

Onianwa, P.C. 2001. Roadside topsoil concentrations of lead and other heavy metals in Ibadan, Nigeria. Soil Sedi. Cont., 10(6): 577591. https://doi.org/10.1080/20015891109446

World Health Organization (WHO).1989. Health guidelines for use of wastewater in agriculture and aquaculture. WHO Technical Report Series 778. Geneva, Switzerland.

WHO/FAO. 2007. Joint FAO/WHO Food standard Programme codex Alimentarius Commission $13^{\text {th }}$ session. Report of the thirty eight session of the Codex Committee on food hygiene, Houston, United States of America, ALINORM07/30/13. 